\title{
Interdependence between human capital determinants and economic development: K-means regional clustering approach for Czechia and Poland
}

\author{
Michał Wielechowski, Denys Cherevyk, Katarzyna Czech, \\ Pavel Kotyza, tukasz Grzęda, Lubos Smutka
}

\begin{abstract}
Objective: The objective of the article is to identify the groups of regions characterised by a similar level of human capital determinants and investigate the relationship between cluster-based human capital determinants and economic development.

Research Design \& Methods: We analyse key demographic, health, educational, labour, technological, and cultural determinants of human capital and the level of regional economic development. The research covers the period 2004-2019 for 14 Czech and 16 Polish regions. We apply k-means clustering improved by PCA using data for human capital determinants. To verify significant differences between distinguished clusters, we apply the Kruskal-Wallis test. To assess the interdependence between human capital determinants and regional economic development, we use Spearman rank correlation.

Findings: We distinguish three clusters for Czechia and four clusters for Poland that differ significantly in terms of human capital determinants level. Moreover, we show that both Czech and Polish clusters significantly differ in the median level of GDP per capita. It implies the existence of interdependence between human capital determinants and economic development. We reveal a positive and significant relationship between GDP per capita and life expectancy, higher education rate, economic activity rate, and Internet access, and a negative and significant relationship between the number of library users and the regional economic development. The results are consistent for Czechia and Poland.
\end{abstract}

Implications \& Recommendations: Our study could create a new perspective for discussing similarities and differences in regional human capital development. The results could help decision-makers to identify the regions that need the most to stimulate the human capital determinants to reduce the differences in human capital, and in the long-term perspective, it might contribute to the regional economic development growth.

Contribution \& Value Added: Most studies analyse the relationship between human capital and economic growth and development using data for given regions or countries separately. Our contribution is that we first distinguish clusters representing regions with similar human capital levels. Then, based on cluster data, we assess the relationship between the human capital determinants and economic development. To the best of our knowledge, there have been no similar regional research studies conducted to daye, including Czechia and Poland.

Article type: research article

Keywords: human capital determinants; economic development, regional clustering; k-means clustering; principal component analysis - PCA; Czechia; Poland

JEL codes: E24, 125, J24

Received: 23 February 2021 Revised: 11 July 2021 Accepted: 2 September 2021

Suggested citation:

Wielechowski, M., Cherevyk, D., Czech, K., Kotyza, P., Grzęda, Ł., \& Smutka, L. (2021). Interdependence between human capital determinants and economic development: K-means regional clustering approach for Czechia and Poland. Entrepreneurial Business and Economics Review, 9(4), 173-194. https://doi.org/10.15678/EBER.2021.090411 


\section{INTRODUCTION}

Economic development is a topic broadly discussed by numerous economic scholars. Over the years, it evolved into an individual economic discipline. However, according to scholars such as Hicks and Streeten (1979) and Sen (1980), global development goals were connected mainly to economic indicators, including Gross National Product. But the effects of Sen and other thoughts contributed to an update in the meaning of development. Since the 1980s, the development of humans and their capabilities is considered the main objective of development. Amartya Sen's philosophy of human capabilities (Sen, 1980) was widely accepted by the international community and, in fact, contributed to the official UN Human Development Index establishment. Nevertheless, as argued by others (Stewart, Ranis \& Samman, 2018), improved human capital is essential for sustainable economic growth.

Although the implementation of human capital into development studies does not have a longlasting history, the idea of human capital is quite old. Sir William Petty (1623-1687) was the first one who tried to define and measure human capital. He believed that labour as the "father of wealth" should be measured and incorporated into national wealth estimation (Folloni \& Vittadini, 2010). Human capital was introduced and popularised as a concept in economic literature by Mincer (1958), Schultz (1961), and Becker (1964). According to them, human capital is created by people equipped with scientific knowledge and skills that can be used to create and use innovations in the economy and to improve practical activity. Others identify human capital as intellectual capital that originates in such attributes as knowledge, skills, relationships, and attitudes (Kianto, Saenz \& Aramburu, 2017; Wang \& Cuervo-Cazurra, 2017; Yusoff, Jantan \& Ibrahim, 2004). Jabłoński (2021) claims that terminological inconsistencies accompanying human capital and appearing among representatives of various economic schools result from different theoretical traditions on which these researchers base their discussions.

Diebolt's and Hippe's (2019) conclusions to a certain extent raise the question whether human capital is the determinant of global growth or is it economic growth that determines human capital development. The endogenous growth theories (Lucas, 1988; Romer, 1986) assume intangible assets to be the fuel of economic growth. However, Mincer (1996) argues that human capital is both the factor and effect of the growth, while Ahmad and French (2011) conclude that an increase in income growth is followed by improved human capital (Ahmad \& French, 2011).

Knight, Loayza, and Villanueva (1993) find that human capital positively affects economic growth. Herbst (2009) claims that human capital significantly influences economic development, including by increasing the capacity of regional economies to absorb and generate technological innovations and improving the region's attractiveness. Access to human capital fosters regional economic development and growth (Lucas, 1988). Accumulation and quality of human capital are considered the key factors of economic growth (Mincer, 1981; Lucas, 1988; Barro, 1991; Mankiw, Romer \& Weil, 1992; De la Fuente \& Doménech, 2006; Erosa, Koreshkova \& Restuccia, 2010; Gennaioli et al., 2013a; Manuelli \& Seshadri, 2014; Balcerzak, 2016, Grzeszczyk, 2020; Shachmurove \& Zilberfarb, 2020).

In the European context, many studies evaluate European regions from the perspective of human capital (Cuaresma et al., 2018; Laskowska \& Dańska-Borsiak, 2017; Martín \& Herranz, 2004; Pater \& Lewandowska, 2015). This article aims to identify the groups of regions characterised by similar human capital indicators for Czechia and Poland separately. We analyse key demographic, health, educational, labour, technological, and cultural determinants of human capital, including migration balance, life expectancy, higher education, economic activity, Internet access, and library users. To our knowledge, there are no other studies using such a broad set of human capital indicators. The literature review presented in the next section confirms that the analysed human capital determinants were properly selected. Based on principal component analysis (PCA) and k-means clustering, we identify the groups of regions characterised by a similar human development status. Moreover, we apply the Kruskal-Wallis test to assess the existence of significant differences between clusters and analysed human capital determinants. Furthermore, we add GDP per capita as a key factor differentiating clusters. Then, based on distinguished clusters, we assess the relationship between analysed human capital determinants and GDP per capita by applying Spearman's rank correlation coefficient. 
Most studies analyse the relationship between human capital and economic growth and development using data for given regions or countries separately (Azam, 2019; Egert, Botev \& Turner, 2020; Gruzina, Firsova \& Strielkowski, 2021; Xu \& Li, 2020). Our contribution is that - contrary to those studies - we first distinguish clusters representing regions with similar human capital levels, and then based on cluster data, we assess the relationship between the human capital determinants and economic development, measured by GDP per capita. Tano (2014) claims that regional differences in economic growth and welfare are rooted in the spatial distribution of human capital. To the best of our knowledge, there have been no similar regional research studies conducted yet, including Czechia and Poland.

The article could help decision-makers identify the regions that most need to stimulate human capital determinants.

The agenda of our article is as follows. The next section will present a review of the scientific literature on human capital determinants, research hypotheses. The posterior section will set out the study's aim and desribe the material and research methods used. The subsequent section will present the empirical findings and discussion, and the final section will offer our conclusions.

\section{LITERATURE REVIEW}

Regions tend to differ due to the spatial unevenness of economies of scale and market forces, in which agglomeration effects lead to a strong concentration of capital and labour in some regions (Biscaia et al., 2017; Kijek \& Matras-Bolibok, 2019). Mitigating economic differences between various regions is not only the task of national and regional governments but also a common approach to regional convergence in the European Union (Alcidi, 2019; Kijek \& Matras-Bolibok, 2020). The European Union applies a complex set of measures to improve the European regions' economic performance and limit existing regional disparities. The cohesion (regional) policy targets business competitiveness, sustainable development, job creation, economic growth, and citizen's quality of life (UNESCO, 2017). The policy itself much attention to human capital development support, mainly by employing two main investment funds: European Social Fund and European Regional Development Fund. Scholars continue a heated discussion about whether the cohesion policy has statistically significant impacts on cohesion (Piętak, 2021).

In the first half of the twentieth century, neoclassical economists identified three factors related to growth: land, capital, labour. In the 1950s, the Solow-Swan model identified those factors as insignificant to technological progress (exogenous), which was a pulling factor of US economic growth (Piętak, 2014). The narrow concept with the only important factor of technological advancement was extended by a list of endogenous factors such as education, quality, and diversity of institutions, along with capital flow, technology, ideas, investments, and human capital (Barro \& Sala-i-Martin, 1992; Piętak, 2014; RoszkoWójtowicz et al., 2019). Since the 1980s, human capital has gained importance in neoclassical (Jorgenson \& Fraumeni, 1992) and endogenous growth models (Lucas, 1988; Romer, 1986).

The World Bank report (2010) identifies that $60-80 \%$ of total country wealth is created by intangible capital, dominated by human capital over the quality of institutions and historical and geographical legacy. In countries that belong to the Organization for Economic Cooperation and Development (OECD), the intangible capital is considered to be the only significant factor of production. Those findings lead to recommendations that human capital investments are a crucial component of the development process.

Since Becker (1964), human capital use and measuring have developed. Currently, the human capital concept is not only used for national growth (at the macro level) but also for corporate purposes (microlevel; Bryl \& Truskolaski, 2017; Buzavaite \& Korsakiene, 2019; Graczyk-Kucharska \& Erickson, 2020). The macro-level measuring methodologies and approaches are divided into two basic categories: direct and indirect measurements. While the indirect approach assumes that current human capital value equals the future discounted value of capital stocks benefits, the direct approach measures stock of human capital based on information on various components via (i) cost-based method, (ii) lifetime income-based method, and (iii) indicator-based method. Alternatively, Liu and Fraumeni (2020) divide human capital measuring methods into monetary- and index-based. The indirect indicator/index-based approach is employed in this article as this approach employs a variety of proxy indicators (United Nations, 2016). 
Statistics Poland identifies six groups of human capital indicators: (i) demography, (ii) health, (iii) education, (iv) labour market, (v) culture, and (vi) science, technology, and innovation. Statistics Poland employs a combination of various related groups supported by the literature. Education and health proxies are common and the most popular (Lim et al., 2018; UNDP, 2020; World Bank, 2021). The Global Human Capital Index published by World Economic Forum also includes education (capacity), labour market (deployment), and science, technology (know-how; World Economic Forum, 2017). Demography, including immigration, is considered an important factor by the United Nations (2016) as it defines newcomers as new human capital assets. According to Bucci and Segre (2011), culture belongs to the endogenous drivers of economic growth, being complementary to human capital. We decided to use six group categories (education, demography, culture, labour market, health, science, and innovations) employing six relevant proxies to identify differences in human capital formation and its effects on regional GDP formation.

Migration leads to the inflow of human capital assets, but also on the contrary, it could result in capital outflow (United Nations, 2016). Migration theory by Sjastaad (1962) compares the utility between given locations. The propensity of migration is positively correlated with human capital performance (Faggian \& McCann, 2006). The outcome of personal, household, and region of residence characteristics are significant in modelling the decision to migrate (Ritsilä \& Ovaskainen, 2001). In this regard some groups of the population are more sensitive to the living and working environment. First of all, it is typical for well-educated youth (Tvaronavičienè et al., 2021) whose perception of wellbeing should be measured with special attention to prevent the negative consequences in demographic sphere. Human capital migration is most often analysed in terms of push and pull factors (Zikic, 2015). Abel and Deitz (2012) reveal only a minimal relationship between the production and stock of human capital in a region. They argue that it is migration patterns that influence the regional structure of human capital. Other studies' results show that the relationship between internal migration and economic growth and development is ambiguous. Etzo (2008) and Bunea (2012) reveal the significant and positive impact of migration on economic growth, while Kirdar and Saracoglu (2008) and Hierro and Maza (2010) observe the opposite relationship, i.e. negative. Each 10\% GDP increase could cause a $0.6 \%$ decrease in net migration (Simionescu et al., 2016). Moreover, Wolszczak-Derlacz (2009) finds no effect of internal migration on economic development in Poland. Borozan (2017), based on Croatian counties' data, shows that the migration flows do not significantly reduce regional disparities in economic development. Based on the results of the above-presented studies, we formulate the following research hypothesis:

H1: Migration balance is positively correlated with the regional economic development level.

Life expectancy at birth is usually used as a proxy of health conditions (Weinberger, 2014). Sachs (2001) proves that every improvement in the life expectancy of society increases economic growth. Lorentzen, McMillan, and Wacziarg (2008) find that life expectancy improvements lead to faster economic growth. However, Acemoglu and Johnson (2007) show that longer life expectancy trigger more rapid population growth but negatively affects income per capita. Based on the results of the abovepresented studies, we put forward the following research hypothesis:

H2: Life expectancy is positively correlated with the regional economic development level.

Many observe direct and indirect relationships between the state of education and economic development (Harbison \& Myers, 1964; Wilson \& Briscoe, 2004; Shafuda \& De, 2020). Using evidence from more than 1500 regions, Gennaioli et al. (2013b) conclude that regional education is the only critical determinant of regional development. Bradley and Taylor (1996) show that the easier access to education and training redound to the regional human capital growth. The OECD data leads to conclusions that one year of longer schooling increases GDP by $6 \%$ (Bassanini \& Scarpetta, 2002). Faggian and McCann (2008), prove on British regional data that higher education is a key factor favouring regional economic development. However, Krueger and Lindahl (2001) illustrate that decreasing returns to education exist in the latter stages of development. Universities and other high educational institutions affect regional economic dynamics, contributing to new ventures and productivity improvements, but only if a region can absorb high-skilled professionals. On the other hand, graduates could decide to migrate out of the 
region. Bennett, Glennerster, and Nevison (1995) claim that the inflow/outflow of graduates into/from a given region indicates the extent to which a region is efficient in acquiring the new human capital. Based on the results of the above-presented studies, we formulate the following research hypothesis:

H3: Higher education rate is positively correlated with the regional economic development level.

Indicators of employability or economic activity serve as a labour market proxy. Economic growth and unemployment are interconnected (Soylu, Çakmak \& Okur, 2018). Thus, the existence of Okun's law is broadly proved from a regional perspective (Freeman, 2000). Laureys (2014) notes that human capital is eroded in times of high unemployment. Ngo et al. (2020) state that human capital and social capital are individual-level important factors affecting employment transition status in rural areas. Based on the results of the above-presented studies, we set the following research hypothesis:

H4: Economic activity is positively correlated with the regional economic development level.

Science, technology, and innovations are proxied by the indicator of Internet access. In particular, the United States of America promote Internet-related human capital, serving as an incubator for new industries and a magnet to attract talents from around the globe (Manyika \& Roxburgh, 2011). For developing countries, steep ICT development can enforce new impulses of economic progress (Bilan et al., 2019). Together with the latest available technologies available at schools, ICT development can affect productivity growth (Máté et al., 2020). The World Bank and the OECD argue that the increase of Internet access rate - as a human capital determinant - positively affects GDP growth (Jiménez, Matus \& Martinez, 2014). Based on OECD countries in 1996-2007, Czernich et al. (2011) find that a 10 percentage point increase in broadband Internet penetration is linked to raised annual per capita growth by 0.9-1.5 percentage points. On the contrary, Diebolt and Hippe (2019) argue that technology is not increasing human capital. Still, human capital shall be understood as a key factor explaining regional disparities in innovation. Based on the results of the above-presented studies, we put forward the following research hypothesis:

H5: Internet access is positively correlated with the regional economic development level.

Sacco and Segre (2009) indicate the lack of research studies focusing on the culture's impact on economic growth. Bucci and Segre (2011) point out that culture may represent an important factor in economic growth. Based on Statistics Poland publication, libraries and reading habits were used as a proxy for the cultural dimension. Using contingent valuation methods, Stejskal, Hájek and Řehák (2019) prove the benefits of public libraries in relation to costs to be fourfold and twelvefold in the case of general libraries and libraries for kids, respectively. Moreover, public libraries often serve as community centres enhancing human capital improvement by facilitating an individual's lifelong learning process (Lo \& Stark, 2020). Libraries offer cheap or free of charge access to resources for educational and recreational purposes (Balapanidou, 2015). According to Varheim (2009), Scott (2011), and Ferguson (2012), public libraries develop social capital. Based on the results of the above-presented studies, we set the following research hypothesis:

H6: Library usage is positively correlated with the regional economic development level.

\section{RESEARCH METHODOLOGY}

The study aimed to identify the groups of regions characterised by a similar level of human capital determinants and investigate the relationship between cluster-based human capital determinants and regional economic development. We conducted the study both for Czechia and Poland. These two neighbour countries represent CEE post-soviet-satellite economies and are characterised by a similar level of Human Development Index (CZ 0.9 and PL 0.88 in 2019; United Nations, 2021).

Our study could create a new perspective for discussing similarities and differences in human capital development from a regional perspective. The research problem was investigated based on data presenting various areas of the studied phenomenon. The main areas were demographic, health, educational, labour, cultural, and technological determinants of human capital, i.e. the balance of migration, life expectancy, higher education rate, employment rate, number of library users, and Internet 
access in 14 regions in Czechia and 16 regions (voivodeships) in Poland. The primary initial list of candidate variables contained 15 determinants. Finally, six human capital determinants representing six different categories were used in cluster analysis. They are presented in Table 1 below.

Table 1. Selected determinants of human capital and the categories they represent

\begin{tabular}{|l|l|}
\hline \multicolumn{1}{|c|}{ Human capital determinant } & \multicolumn{1}{c|}{ Category } \\
\hline Migration balance & demography \\
\hline Life expectancy & health \\
\hline Higher education & education \\
\hline Economic activity & labour \\
\hline Internet access & technology \\
\hline Library users & culture \\
\hline
\end{tabular}

Source: own elaboration based on Statistics Poland.

Migration stands for the number of people changing their residence to or from a given area. In our study, migration balance refers to the crude rate of net interregional migration plus a statistical adjustment to the average population in that particular year. The value of migration balance is expressed per 1000 residents. Life expectancy refers to the average life expectancy at birth of all population members in the particular region. Higher education stands for the rate of tertiary education among the population aged 15 and over. Economic activity equals the economic activity rate, i.e. the percentage of active persons in relation to the total working-age population, both employed and unemployed. Internet access refers to the rate of households with Internet access among all the households in the particular region. Library users stand for the number of active library readers per 1000 residents. The above-mentioned human capital determinants were selected iteratively to effectively differentiate human capital status in all $14 \mathrm{Czech}$ and 16 Polish regions. Moreover, they belong to the most frequently used by Statistics Poland (GUS, 2019). Furthermore, economic development is measured by Gross Domestic Product per capita.

Data came from the Local Data Bank (LDB) and the public database of the Czech Statistical Office (2021). The LDB by Statistics Poland is Poland's largest database of the economy, households, innovation, public finance, society, demography, and the environment. The LDB offers over 40,000 statistical data and indicators that describe statistical towns, communes, counties, voivodeships, and entire Poland (Local Data Bank, 2020). The Czech Public Database is a unified and basic data source for the presentation of statistical data. It collects all standard statistical outputs of the Czech Statistical Office, but it also stores data from external sources, especially from ministries and other state statistical services.

We standardised the variables to make them comparable between regions of different size and population. We used annual data which are taken from the Local Data Bank and Czech Public Database. The research covered the period 2004-2019, which was as up-to-date as possible.

Clustering is the task of assigning a set of objects into groups (called clusters) so that objects in the same cluster are more similar (in some sense or another) to each other than to those in other clusters (Bagirov, 2008). Interest in regional clusters and their role in economic development has grown substantially among academics, economic development professionals, and firm managers over the last several years. Cluster analysis allows us to draw useful conclusions in economic studies (MacQueen, 1967; Imandoust \& Bolandraftar, 2013). Clustering is an important part of data exploratory analysis, using for identity-hidden knowledge from data by group. K-means nearest neighbour is a popular algorithm using for unsupervised learning, based only on input vectors known labels or outcomes. The method is useful in numerical segmentation of economic data and was introduced by MacQuenn (1967).

To cluster Czech and Polish regions according to the human capital performance, we applied kmeans clustering developed by Linde, Buzo, and Gray (1980). The number of clusters was identified based on gap statistic (Tibshirani, Walther, \& Hastie, 2001). The lowest gap statistic indicates the optimal number of groups that should be distinguished. Then, we segmented regions considering the selected human capital determinants. The goal of the k-means procedure was to find the closest distance of points from the cluster's centre (Ding \& He, 2004). 
We used the principal component analysis PCA to more effective clusters distinction as Ding and He (2004) and Honda, Notsu, and Ichihashi (2010) suggest. The solution helped mark the largest variations and reduced noise from values for a better-performing k-means algorithm. Finally, clustering was used on the transformed dataset to PCA with dimensional reduction components. The results were presented in the form of a hierarchical analysis dendrogram and PCA figure. The obtained estimations - subjected to a hierarchical analysis based on Ward Criterion's method (Ward, 1963) - were linked threes measure of dissimilarity between two clusters and was defined as the sum of the squared deviations within these clusters.

Moreover, by applying the Kruskal-Wallis test (Kruskal, 1952; Kruskal \& Wallis, 1952), we assessed the existence of significant human capital determinants' differences between the distinguished clusters. Furthermore, we investigated whether the selected clusters significantly differ in terms of economic development measured by the GDP per capita.

Then, we applied Spearman's rank correlation coefficients and corresponding significance test to measure the relationship between the analysed human capital determinants and economic development level in each cluster separately.

The entire analysis was performed in the statistical computing environment $R$.

\section{RESULTS AND DISCUSSION}

The research was conducted separately for Czechia and Poland. We present the results in the alphabetical order of the analysed countries' names.

\section{Czechia}

We analysed 14 Czech regions. Based on the estimated gap statistics for a different number of clusters, we indicated three as the optimal number of clusters. We performed a cluster analysis based on the k-means algorithm. To check the robustness of the cluster analysis results, we applied a principal component analysis (PCA). The analysis aimed to classify the Czech regions into one of three groups, considering six selected human capital determinants, including migration balance, life expectancy, higher education, economic activity, Internet access, and library users.

Figure 1 below presents the results of the principal component analysis (PCA), which proved the existence of significant differences in the regional clustering of human capital in Czechia. In terms of PCA, some regions appeared closer to each other. Prague region was the farthest from other the 13 regions, i.e. the least similar to others. Moreover, Karlovy Vary region, the smallest and the weakest in GDP, had a certain distance from the others.

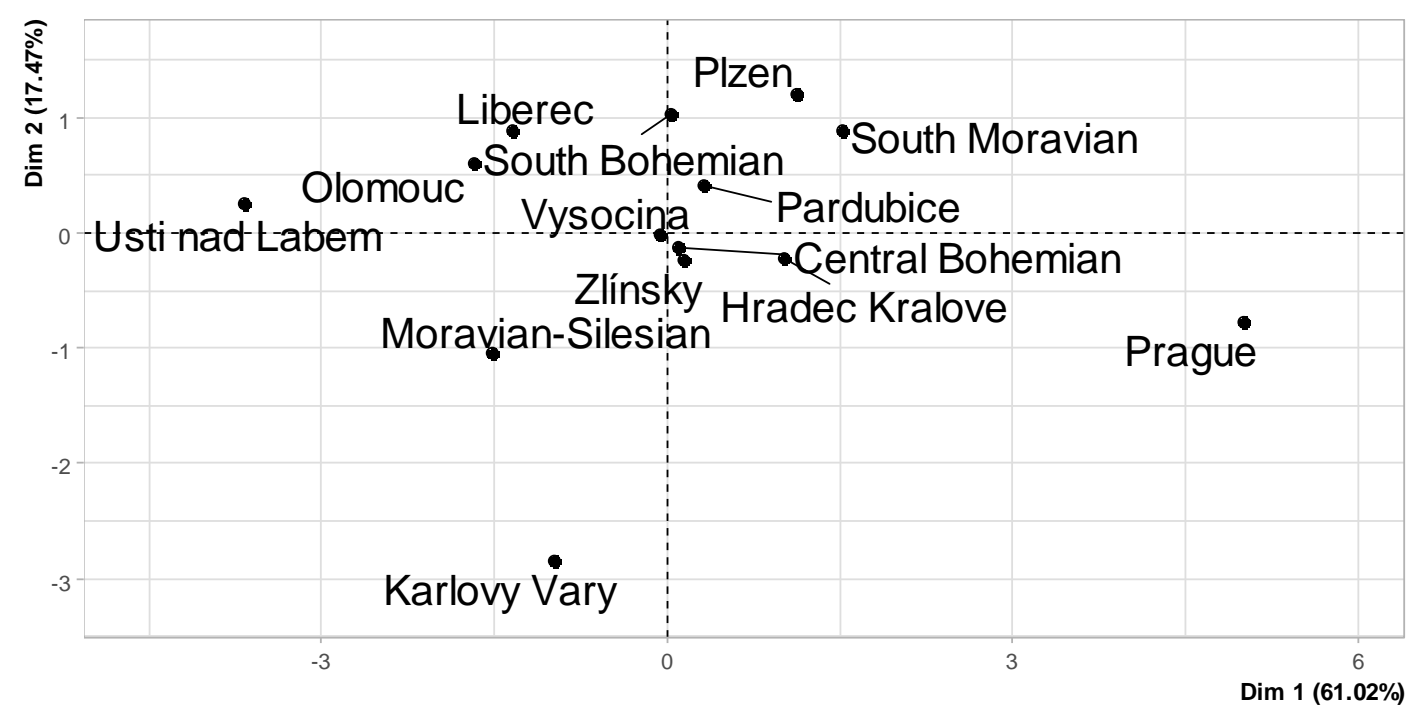

Figure 1. Regional clustering of human capital in Czechia based on PCA

Source: own elaboration. 
K-means regional clustering (Figure 2, Figure 3) and principal component analysis (PCA; Figure 1) indicated the existence of significant differences in human capital between the distinguished clusters (groups) composed of Czech regions. The dendrogram revealed clusters in which regions were combined according to their similarity. For example, Olomouc and Liberec Regions were closest to each other, which meant they are also the most similar, while the Prague region was the farthest from other regions, i.e. it was the most different.

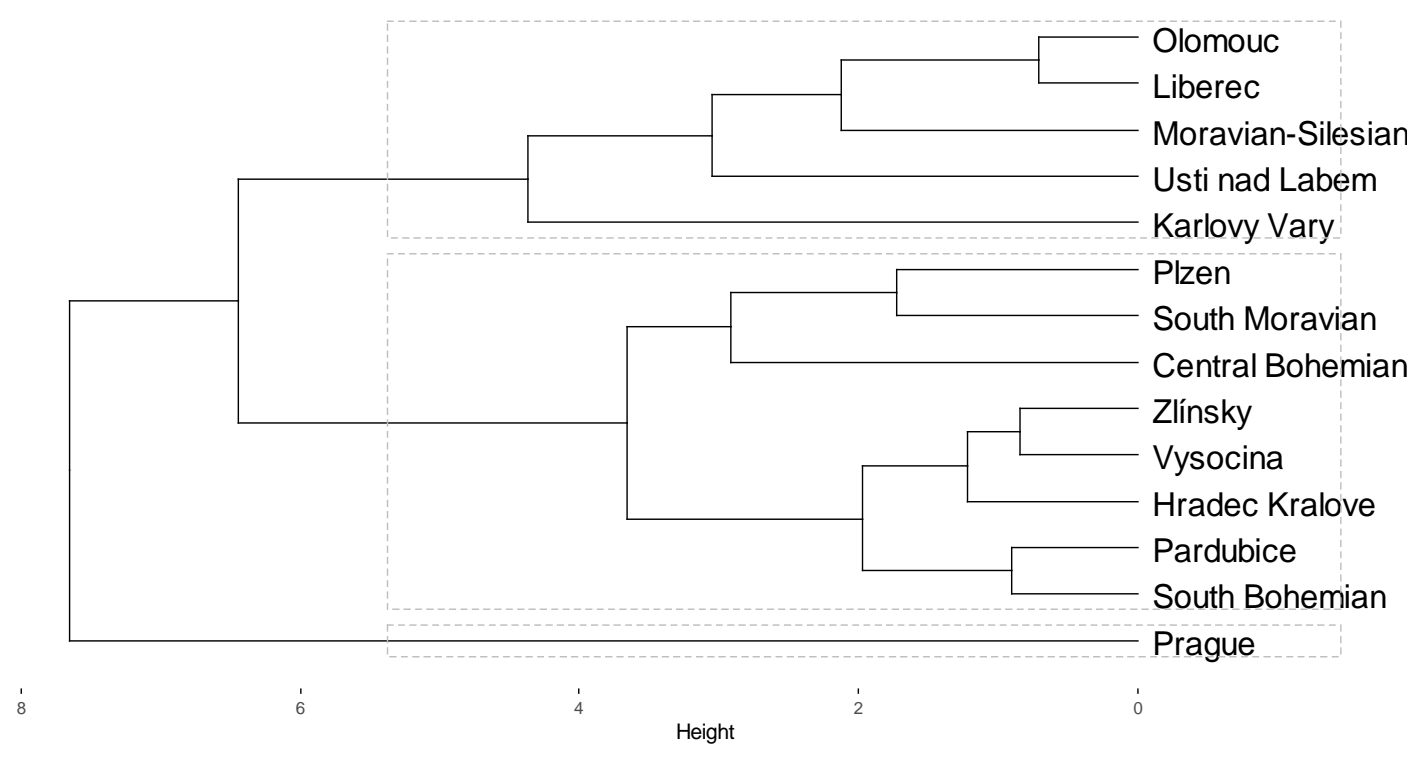

Figure 2. K-means regional clustering of human capital in Czechia

Source: own elaboration.

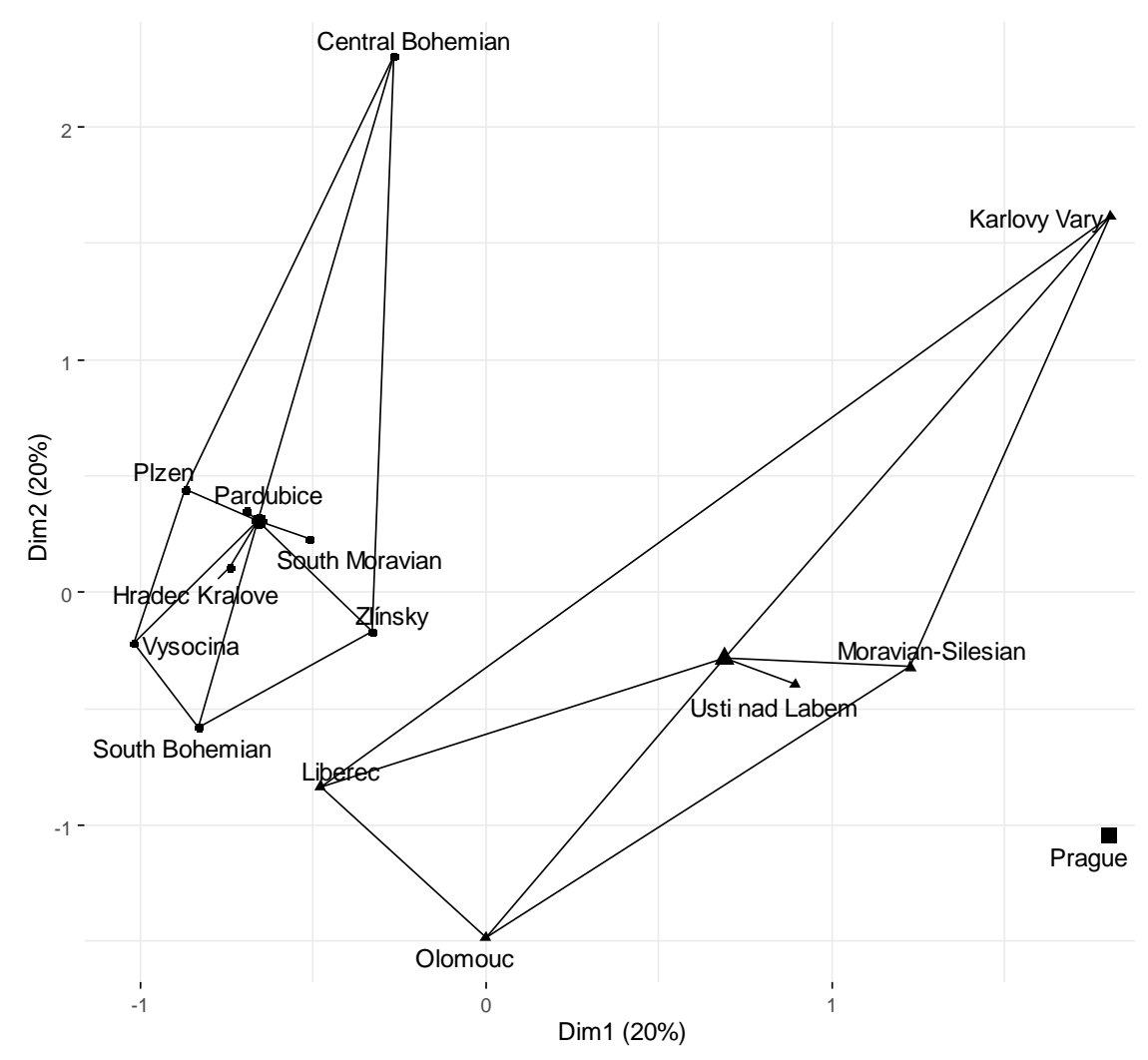

Figure 3. Cluster plot based on k-means clustering for Czechia Source: own elaboration. 
Cluster I represented five Czech regions characterised by the lowest values of all six analysed human capital determinants (see Table 2). Those were considered to be lagging regions, have the weakest economic performance, and many internal problems. Their situation was either related to the transformation phase - as many industries did not succeed - industrial orientation (such as mining), or their geographical location (being in the periphery). Those clusters were expected to be still eligible for EU regional policy funding. Cluster II referred to eight Czech regions with the average values of human capital determinants, apart from migration balance. The positive migration balance resulted from the substantial inflow of people to Central Bohemian region due to its geographical location close to Prague and lower real estate prices, among other things.

Those regions were expected to be phased out of the regional policy funding and moved from less developed to transition ones. In general, those eight regions were not suffering from high unemployment. They were able to attract foreign direct investments (e.g. in manufacturing like Hradec Kralove, Plzen, Zlin, or in services like the South Moravian Region) or are closely linked to the capital city as the Central Bohemian Region. Cluster III includes only Prague, the capital city, and it characterises the largest values of analysed human capital determinants (apart from migration balance). The Prague Region is considered one of the most developed regions in the EU measured by GDP per capita to regional $\mathrm{EU}$ average. Prague is characterised by a negative interregional migration balance, but on the contrary, a positive migration balance from abroad. It is the administrative centre with the highest number of public universities, public libraries, medical institutions, and a high demand for qualified labour.

Table 2. Mean values of human capital determinants and GDP per capita in distinguished Czech clusters

\begin{tabular}{|c|c|c|c|c|}
\hline Human capital determinants & Cluster I & Cluster II & Cluster III & Czechia \\
\hline Migration balance & -1.94 & 0.432 & -0.59 & -0.49 \\
\hline GDP & 9963.08 & 11422.37 & 29570.95 & 12197.52 \\
\hline Life expectancy & 77.46 & 78.76 & 79.93 & 78.38 \\
\hline Higher education & 12.70 & 15.30 & 34.10 & 15.74 \\
\hline Economic activity & 0.74 & 0.76 & 0.80 & 0.75 \\
\hline Internet access & 67.23 & 71.17 & 76.07 & 70.11 \\
\hline Library users & 122.81 & 138.33 & 173.46 & 135.30 \\
\hline
\end{tabular}

Source: own study.

Our next task was to verify whether the differences between the distinguished clusters are statistically significant. For this purpose, we applied the Kruskal-Wallis test.

The results presented in Table 3 implied significant differences in median values of all six analysed human capital determinants between two out of three distinguished clusters. A significant difference between the analysed groups of Czech regions applied to life expectancy at $1 \%$ significance level, Internet access at $5 \%$ significance level, along with migration balance, higher education, economic activity, and library users at $10 \%$ significance level. Moreover, the results of the Kruskal-Wallis test indicated that the distinguished clusters differed in median GDP per capita level at the $5 \%$ significance level. It implied that the level of GDP per capita and human capital determinants are linked to each other.

Table 3. Results of Kruskal-Wallis test for Czechia

\begin{tabular}{|l|c|r|}
\hline \multicolumn{1}{|c|}{ Human capital determinants } & Chi Sq & p-value \\
\hline Migration balance & 4.85 & $*$ \\
\hline Life expectancy & 10.03 & $* * *$ \\
\hline Higher education & 5.74 & $*$ \\
\hline Economic activity & 5.27 & $* *$ \\
\hline Internet access & 7.35 & $*$ \\
\hline Library users & 5.74 & $* *$ \\
\hline GDP per capita & 7.97 & $*$ \\
\hline
\end{tabular}

Notes: $* * *, * *$ and $*$ denote statistical significance at the $1 \%, 5 \%$, and $10 \%$ significance level, respectively.

Source: own elaboration of the public database of the Czech Statistical Office (2021). 
Table 4 contains the estimated Spearman Rank correlation coefficients with corresponding significance tests between human capital determinants and economic development measured by GDP per capita. Our study revealed significant relationships between GDP per capita and five out of six analysed determinants. Surprisingly, we did observe a significant relationship between migration balance and economic development. In the case of life expectancy, higher education, Internet access, and economic activity, the relationship with GDP per capita was positive. Unexpectedly, the cultural human capital determinant (library users) was at the same time negatively correlated with economic development. The results agreed with $\mathrm{H} 2, \mathrm{H} 3, \mathrm{H} 4, \mathrm{H} 5$, while contradicted $\mathrm{H} 6$. Moreover, we did not find a statistically significant relationship between migration balance and GDP $(\mathrm{H} 1)$.

Table 4. The relationship between human capital determinants and GDP per capita in Czechia: Spearman rank correlation

\begin{tabular}{|c|l|l|l|l|l|l|}
\hline Cluster & $\begin{array}{l}\text { Migration bal- } \\
\text { ance and GDP }\end{array}$ & $\begin{array}{c}\text { Life expectancy } \\
\text { and GDP }\end{array}$ & $\begin{array}{c}\text { Higher educa- } \\
\text { tion and GDP }\end{array}$ & $\begin{array}{c}\text { Economic ac- } \\
\text { tivity and GDP }\end{array}$ & $\begin{array}{c}\text { Internet access } \\
\text { and GDP }\end{array}$ & $\begin{array}{c}\text { Library users } \\
\text { and GDP }\end{array}$ \\
\hline I & 0.533 & $0.588^{*}$ & $0.564^{*}$ & $0.588^{*}$ & $0.600^{*}$ & $-0.600^{*}$ \\
\hline II & -0.567 & $0.721^{* *}$ & $0.709^{* *}$ & $0.721^{* *}$ & $0.721^{* *}$ & $-0.855^{* * *}$ \\
\hline III & -0.167 & $0.661^{* *}$ & $0.648^{* *}$ & $0.636^{*}$ & $0.661^{* *}$ & $-0.709^{* *}$ \\
\hline
\end{tabular}

Notes: ${ }^{* *}, * *$ and $*$ denote statistical significance at the $1 \%, 5 \%$, and $10 \%$ significance level, respectively.

Source: own study.

\section{Poland}

We analysed 16 Polish regions (voivodeships). Based on the estimated gap statistics for a different number of clusters, we indicated four as the optimal number of clusters. As in the case of the analysis of Czech regions, we performed clustering analysis based on the k-means algorithm and apply a principal component analysis (PCA) to check the robustness of the clustering analysis results. The analysis sought to classify the voivodeships into one of the four groups while considering six selected human capital determinants, including migration balance, life expectancy, higher education, economic activity, Internet access, and library users. The k-means regional clustering analysis grouped Polish voivodeships into four clusters. The results showed significant differentiation of voivodeships based on the determinants included.

Figure 4, presenting the results of the principal component analysis (PCA), proved the existence of significant differences in the regional clustering of human capital in Poland. In terms of PCA, some regions were closer to each other. Masovian voivodeship, including Warsaw, was the farthest from the other 15 regions, i.e. the least similar to others. This result is similar to Czechia, in which the Prague Region with the capital city greatly differs from other regions.

K-means regional clustering (Figure 5, Figure 6) and PCA (Figure 4) indicated the existence of significant differences in human capital between the distinguished clusters (groups) composed of Polish voivodeships. The dendrogram below reveals clusters in which regions were combined according to their similarity. According to our study Lublin and Holly Cross were closest to each other, which means they also were the most similar, while the Masovian voivodeship was the furthest from other Polish regions, i.e. the latter region differed the most from others and belonged to a homogenous group. The most numerous cluster consisted of seven voivodeships.

Cluster A - the most numerous group - contains the regions characterised by most human capital determinants' mean values that remained below the Polish average and the lowest GDP per capita (see Table 5). Cluster A contains the regions located in the eastern part of Poland. A relatively high level of economic activity could have been explained by the vast majority of this cluster is one of Poland's most agricultural regions, with high hidden unemployment. Cluster B - representing four voivodeships with the most important economic centres (regional capital cities), namely Krakow, Wroclaw, Poznan, and Gdansk - was characterised by positive migration balance and the level of other five human capital determinants over the Polish average. Cluster $\mathrm{C}$ - containing four voivodeships - was characterised by the lowest mean levels of life expectancy, higher education, and economic activity among the four distin- 
guished groups, along with a negative migration balance. Cluster D - containing only Masovian voivodeship with Poland's capital of Warsaw - was characterised by the largest values of all analysed human capital determinants and highest GDP per capita among the distinguished clusters.

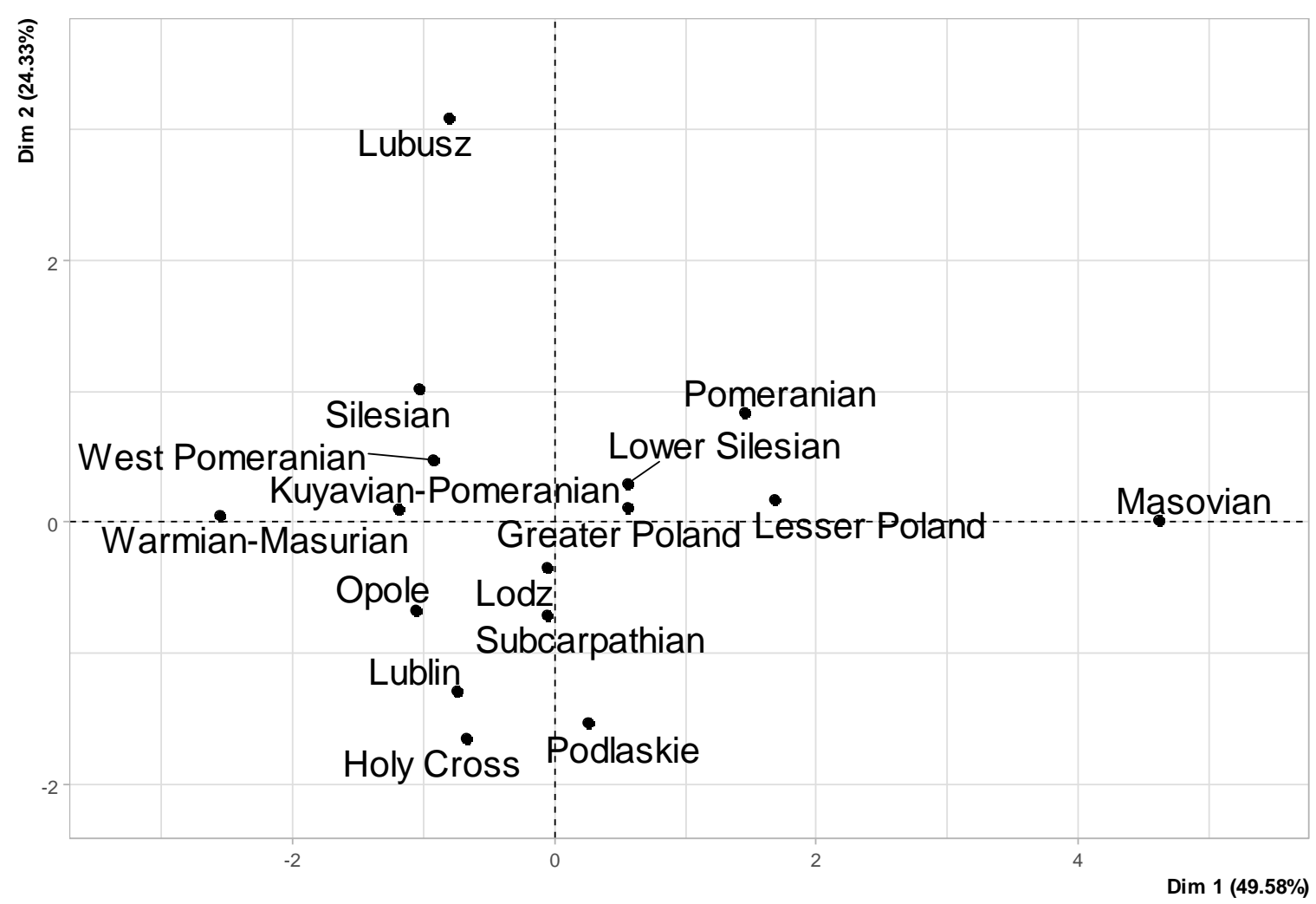

Figure 4. Regional human capital clustering in Poland based on PCA Source: own elaboration.

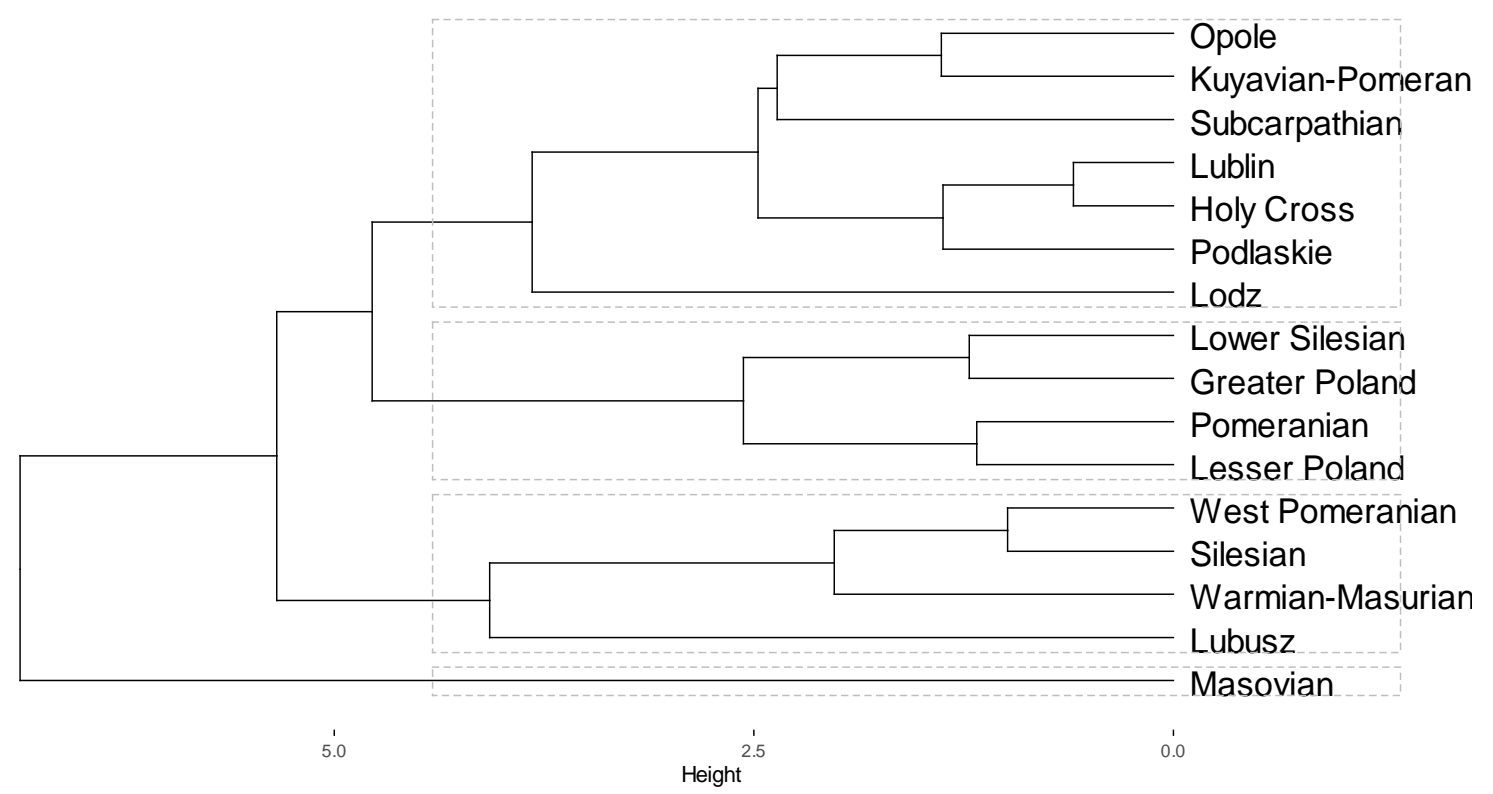

Figure 5. K-means regional clustering of human capital in Poland: a dendrogram based on PCA transforming Source: own elaboration. 


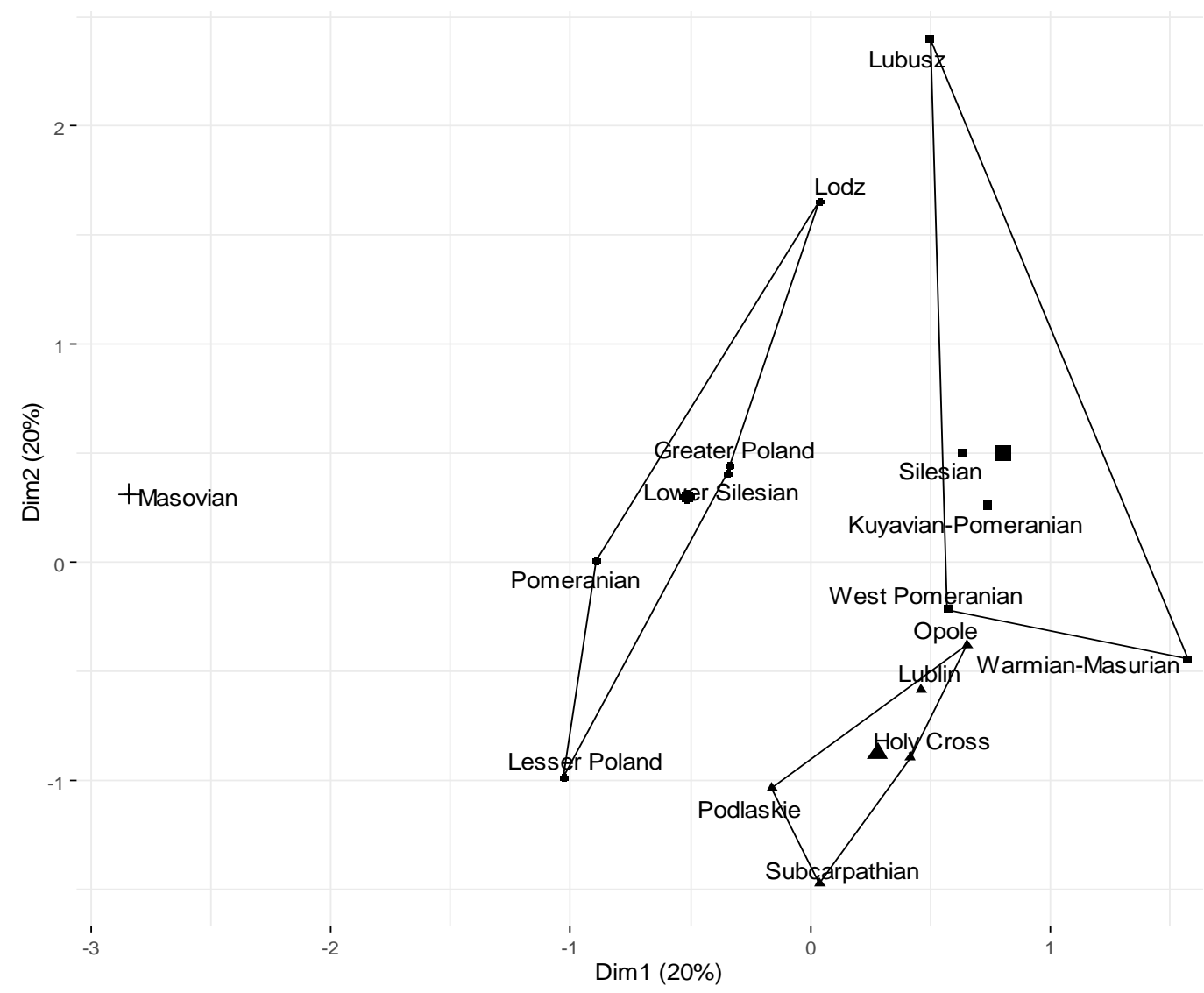

Figure 6. Cluster plot based on k-means clustering for Poland Source: own elaboration.

Table 5. Mean values of human capital determinants and GDP per capita in Polish clusters

\begin{tabular}{|l|r|r|r|r|r|}
\hline \multicolumn{1}{|c|}{ Human capital determinants } & \multicolumn{1}{c|}{ Cluster A } & \multicolumn{1}{c|}{ Cluster B } & \multicolumn{1}{c|}{ Cluster C } & \multicolumn{1}{c|}{ Cluster D } & \multicolumn{1}{c|}{ Poland } \\
\hline Migration balance & -1.47 & 0.70 & -1.21 & 2.43 & -0.62 \\
\hline Life expectancy & 77.16 & 77.34 & 76.42 & 77.46 & 77.04 \\
\hline Higher education & 18.17 & 20.15 & 17.62 & 28.15 & 19.15 \\
\hline Economic activity & 73.49 & 73.31 & 70.01 & 77.88 & 72.85 \\
\hline Internet access & 60.13 & 65.91 & 67.37 & 67.68 & 63.86 \\
\hline Library users & 150.42 & 169.19 & 161.60 & 176.62 & 159.54 \\
\hline GDP per capita & 6588.09 & 8576.49 & 7331.02 & 13456.29 & 7700.19 \\
\hline
\end{tabular}

Source: own study.

Our next task was to verify whether the differences between the distinguished clusters are statistically significant. For this purpose, we applied the Kruskal-Wallis test.

The results presented in Table 6 indicated that there are significant differences in median values of four out of six analysed human capital determinants between at least two out of four distinguished clusters. A significant difference between analysed groups of Polish voivodeships applied to migration balance at $1 \%$ significance level, economic activity at $5 \%$ significance level, along with life expectancy and higher education at $10 \%$ significance level. However, we did not reveal the significant differences in median values of technological and cultural determinants among distinguished clusters. Moreover, the results of the Kruskal-Wallis test showed that the distinguished clusters differed in the median level of GDP per capita at 5\% significance level. Similarly to Czechia, the results implied that the GDP per capita and human capital determinants remain in the relationship. The Kruskal-Wallis test results indicated that migration balance, life expectancy, higher education, and economic activity significantly impacted the regional differentiation of human capital in Poland. 
Table 6. Results of one-factor analysis of variance: the Kruskal-Wallis test for Poland

\begin{tabular}{|l|c|r|}
\hline \multicolumn{1}{|c|}{ Human capital determinants } & Chi Sq & p-value \\
\hline Migration balance & 11.40 & $* * *$ \\
\hline Life expectancy & 7.32 & $*$ \\
\hline Higher education & 7.57 & $* *$ \\
\hline Economic activity & 11.03 & - \\
\hline Internet access & 6.19 & - \\
\hline Library users & 2.59 & $* *$ \\
\hline GDP & 11.19 & $*$ \\
\hline
\end{tabular}

Notes: ${ }^{* * *}, * *$ and $*$ denote statistical significance at the $1 \%, 5 \%$, and $10 \%$ significance level, respectively.

Source: own study.

Table 7 presents the estimated Spearman rank correlation coefficients with corresponding significance tests between human capital determinants and economic development measured by GDP per capita. Our study revealed significant relationships between GDP per capita and five out of six analysed determinants. However, we did not observe a significant relationship between the migration balance and economic development apart from cluster B. In the case of life expectancy, higher education, Internet access, and economic activity, the relationship with GDP per capita was strongly positive, i.e. above 0.7 . Surprisingly, the number of public library users negatively correlated with economic development. Table 7 results indicated the similarities between Poland and Czechia. The results agreed with $\mathrm{H} 2, \mathrm{H3}, \mathrm{H} 4, \mathrm{H} 5$, while contradicted H6. Moreover, apart from cluster B, we did not find a statistically significant relationship between migration balance and GDP (H1).

Table 7. The relationship between human capital determinants and GDP per capita in Poland: Spearman rank correlation

\begin{tabular}{|c|l|l|l|l|l|l|}
\hline $\begin{array}{c}\text { Clus- } \\
\text { ter }\end{array}$ & $\begin{array}{c}\text { Migration bal- } \\
\text { ance and GDP }\end{array}$ & $\begin{array}{c}\text { Life expectancy } \\
\text { and GDP }\end{array}$ & $\begin{array}{c}\text { Higher educa- } \\
\text { tion and GDP }\end{array}$ & $\begin{array}{c}\text { Economic ac- } \\
\text { tivity and GDP }\end{array}$ & $\begin{array}{c}\text { Internet access } \\
\text { and GDP }\end{array}$ & $\begin{array}{c}\text { Library users } \\
\text { and GDP }\end{array}$ \\
\hline A & 0.143 & $0.654^{* *}$ & $0.753^{* * *}$ & $0.736^{* * *}$ & $0.736 * * *$ & $-0.753^{* * *}$ \\
\hline B & $0.580^{* *}$ & $0.797^{* * *}$ & $0.863 * * *$ & $0.846 * * *$ & $0.857 * * *$ & $-0.796^{* * *}$ \\
\hline C & 0.061 & $0.659 * *$ & $0.742 * * *$ & $0.742 * * *$ & $0.736 * * *$ & $-0.740 * * *$ \\
\hline D & 0.122 & $0.809 * * *$ & $0.852 * * *$ & $0.843^{* * *}$ & $0.819 * * *$ & -0.423 \\
\hline
\end{tabular}

Notes: ${ }^{* * *}, * *$ and $*$ denote statistical significance at the $1 \%, 5 \%$, and $10 \%$ significance level, respectively.

Source: own study.

\section{DISCUSSION}

The regional cluster analysis and Kruskal-Wallis test results for Czechia and Poland show that distinguished clusters differ significantly not only in terms of the level of analysed human capital determinants but also in the level of economic development. This implies the existence of an interdependence between the above-mentioned variables, which agrees with broad literature base (Mincer, 1981; Lucas, 1988; Barro, 1991; Mankiw et al., 1992; De la Fuente \& Doménech, 2006; Erosa et al., 2010; Gennaioli et al., 2013a; Manuelli \& Seshadri, 2014; Balcerzak, 2016).

Based on the distinguished clusters, we revealed a significant relationship between GDP per capita and analysed human capital determinants, i.e. life expectancy, higher education, economic activity, Internet access, and library users. Naturally, we are conscious that human capital is only a partial determinant of economic growth. Ogbeifun and Shobande (2021) show that, apart from human capital, other important economic development determinants are savings rate and trade openness.

We prove the positive relationship between life expectancy as a proxy of health services and economic growth. Our results are in line with Sachs (2001) and Lorentzen et al. (2008). In general, health is understood to have a positive relationship to GDP growth. However, Ogbeifun and Shobande (2021) present that life expectancy has adverse effects on growth. Our sample is rather balanced, and we do 
not observe large differences in life expectancy values. This leads us to the assumption that life expectancy is rather a national-wide issue related to the central health system.

Together with health, education is seen as the second most important factor of human capital (Biscaia et al., 2017; Czapiewski \& Janc, 2019; Ogbeifun \& Shobande, 2021; Ogundari \& Awokuse, 2018), which has a positive effect on economic growth. As expected, our results confirm other researchers' findings on the positive and significant relationship between higher education rate and economic development level. Acquired tertiary education differs among regions. It is not only about the availability of tertiary education institutions; the frequent factor for interregional migration towards capital cities is the lack of opportunities. Thus, graduates' inflow or their capturing indicates a regional potential for human capital formation (Bennett et al., 1995).

Migration is the only variable that has a statistically insignificant correlation. Even though it is migration insignificant, we still observe high differences among selected regions. Some are more attractive for national migration flows. Our insignificant results are consistent with other studies, including Derlacz-Wolszczak (2009) and Borozan (2017). However, it is important to note that the immigration of university-educated labour significantly impacts the economic development and competitiveness of territories (Oliinyk et al., 2021) and vice versa high intensity of skilled emigration can cause disastrous effect on country's intellectual potential restoring (Mishchuk et al., 2019). Our statistical insignificance could be affected by several issues, and it could result from data selection: our selected indicator is interregional migration, which does not take into consideration international labour movements.

Economic activity positively affects GDP. Our results agree with our expectations. The more people are economically active, the higher the expected GDP. This assumption is confirmed by Soylu et al. (2018). The rate of economically active population differs among selected regions, and it is affected by transition phase, location, or economic focus. Local governments use the opportunities and possibilities they have to improve the values. However, local policy-makers may not have the competencies to start a demographic boom. Nevertheless, they certainly acquire indirect possibilities.

In selected countries, Internet access is a national-wide aspect, although we observed differences among regions. However, the high-speed Internet availability is already sufficient in both studied countries, as both countries are covered by $4 \mathrm{G}$ mobile networks. Thus, differences in the Internet penetration are related to other factors than the Internet availability. Although we observe that the rate of Internet access is positively related to the level of GDP per capita - and similar results are confirmed by Jiménez et al. (2014) or Czernich et al. (2011) - we are sceptical of the view that further increase in the Internet penetration will be massively reflected in GDP per capita growth.

Finally, our results surprisingly indicate that the number of library users is negatively correlated with GDP per capita. The observed relationship contrasts to Stejskal, Hájek and Řehák (2019). The explanation for our results might be rooted in the level of country development level. Both, Czechia and Poland belong to economically developed European Union members, where people purchase books, both in physical and electronic form, instead of borrowing. Wojciechowska (2021) adds that public libraries today provide many services connected to social capital creation apart from access to information. Moreover, public libraries encourage social inclusion, civic engagement, community involvement and promote economic vitality (Scott, 2011). Although the literature supports the role of public libraries in regional development, we do not observe this in our study.

\section{CONCLUSIONS}

Our analysis is based on the 2004-2019 annual regional data on key demographic, health, educational, labour, technological, and cultural determinants of human capital in Czechia and Poland. The broad literature review confirmed the validity of using the following human capital determinants in the analysis: migration balance, life expectancy, higher education, economic activity, Internet access, and library users.

When considering analysed human capital determinants, the K-means clustering allowed us to distinguish three clusters for Czechia and four clusters that grouped Polish voivodeships with significant differences. The principal component analysis proved the validity of the conducted clustering. Using 
the Kruskal-Wallis test, we observed significant differences in median values of human capital determinants between distinguished clusters for both Czechia and Poland.

Moreover, the results of the Kruskal-Wallis test showed that distinguished clusters significantly differed in the median level of GDP per capita. It implies the existence of economic development and level of human capital determinants interdependence.

Our study revealed a positive and significant relationship between GDP per capita level and the four analysed human capital determinants, i.e. life expectancy, higher education rate, economic activity rate, and Internet access. However, we surprisingly found that the number of library users is negatively related to the regional economic development level. We found that the relationship between the migration balance and GDP per capita level is insignificant. The results are consistent for Czechia and Poland and correspond to the results of other studies.

Our research may create a new perspective for discussing similarities and differences in human capital development from a regional perspective. The results could help decision-makers - local and national governments - to identify the regions that most require to stimulate their human capital determinants so as to reduce differences in human capital level among Czech and Polish regions, which in the long term, will contribute to regional economic development growth. This is indicated by our results that confirm the positive correlation between the level of GDP per capita and the four analysed determinants of human capital, i.e. life expectancy, higher education rate, economic activity, and Internet access. Our study shows that to ensure a more sustainable development of individual regions and eliminate interregional differences, authorities should pay more attention to and invest in health care, education system, new technologies, and the stabilisation of labour markets.

We are aware that our study has drawbacks. Firstly, the number of analysed human capital determinants and the length of the research period is limited due to data availability. Secondly, the selection of determinants might be viewed as subjective. Thirdly, our clustering regional analysis is based on a limited number of regions, i.e. 14 Czech and 16 Polish regions. Fourthly, the analysed data come from regional databases, and there might be differences between local data collection methodologies.

A challenge for future research is to conduct regional clustering analysis based on all European Union countries and, secondly, investigate the economic and social impact of the Covid-19 pandemic on the regional clustering of human capital in Czechia and Poland.

\section{REFERENCES}

Abel, J. R., \& Deitz, R. (2012). Do colleges and universities increase their region's human capital? Journal of Economic Geography, 12(3), 667-691. https://doi.org/10.1093/jeg/lbr020

Acemoglu, D., \& Johnson, S. (2007). Disease and Development: The Effect of Life Expectancy on Economic Growth. Journal of Political Economy, 115(6), 925-985. https://doi.org/10.1086/529000

Ahmad, N., \& French, J. J. (2011). DECOMPOSING THE RELATIONSHIP BETWEEN HUMAN CAPITAL AND GDP: AN EMPIRICAL ANALYSIS OF BANGLADESH. The Journal of Developing Areas, 44(2), 127-142.

Alcidi, C. (2019). Economic Integration and Income Convergence in the EU. Intereconomics, 54(1), 5-11. https://doi.org/10.1007/s10272-019-0783-6

Azam, M. (2019). Relationship between energy, investment, human capital, environment, and economic growth in four BRICS countries. Environmental Science and Pollution Research, 26(33), 34388-34400. https://doi.org/10.1007/s11356-019-06533-9

Bagirov, A. M. (2008). Modified global -means algorithm for minimum sum-of-squares clustering problems. Pattern Recognition, 41(10), 3192-3199. https://doi.org/10.1016/j.patcog.2008.04.004

Balapanidou, A. (2015). The challenging role of public libraries as providers of lifelong learning opportunities for personal and social skills development. International Journal of Teaching and Education, 3(2), 1-16.

Balcerzak, A. P. (2016). Multiple-criteria Evaluation of Quality of Human Capital in the European Union Countries. Economics \& Sociology, 9(2), 11-26. https://doi.org/10.14254/2071-789X.2016/9-2/1

Barro, R. J. (1991). Economic Growth in a Cross Section of Countries. The Quarterly Journal of Economics, 106(2), 407. https://doi.org/10.2307/2937943 
Barro, R. J., \& Sala-i-Martin, X. (1992). Convergence. Journal of Political Economy, 100(2), 223-251. https://doi.org/10.1086/261816

Bassanini, A., \& Scarpetta, S. (2002). Does human capital matter for growth in OECD countries? A pooled meangroup approach. Economics Letters, 74(3), 399-405. https://doi.org/10.1016/S0165-1765(01)00569-9

Becker, G. S. (1964). Human Capital: A Theoretical and Empirical Analysis with Special Reference to Education, First Edition. NBER.

Bennett, R., Glennerster, H., \& Nevison, D. (1995). Regional Rates of Return to Education and Training in Britain. Regional Studies, 29(3), 279-295. https://doi.org/10.1080/00343409512331348963

Bilan, Y., Mishchuk, H., Samoliuk, N., \& Grishnova, O. (2019). Ict And Economic Growth: Links And Possibilities Of Engaging. Intellectual Economics, 13(1), 93-104.

Biscaia, R., Teixeira, P., Rocha, V., \& Cardoso, M. F. (2017). Higher Education, Human Capital, and Regional Dynamics in Southern Europe. In M. Fonseca \& U. Fratesi (Eds.), Regional Upgrading in Southern Europe (pp. 323-344). Springer International Publishing. https://doi.org/10.1007/978-3-319-49818-8_14

Borozan, D. (2017). Internal Migration, Regional Economic Convergence, and Growth in Croatia. International Regional Science Review, 40(2), 141-163. https://doi.org/10.1177/0160017615572889

Bradley, S., \& Taylor, J. (1996). Human Capital Formation and Local Economic Performance. Regional Studies, 30(1), 1-14. https://doi.org/10.1080/00343409612331349438

Bryl, Ł., \& Truskolaski, S. (2017). Human Capital Reporting and Its Determinants by Polish and German Publicly Listed Companies. Entrepreneurial Business and Economics Review, 5(2), 195-210. https://doi.org/10.15678/EBER.2017.050211

Bucci, A., \& Segre, G. (2011). Culture and human capital in a two-sector endogenous growth model. Research in Economics, 65(4), 279-293. https://doi.org/10.1016/j.rie.2010.11.006

Bunea, D. (2012). Provincial Assessment of Convergence and Migration in Spain. Journal of Statistical and Econometric Methods, 1(2), 9-30.

Buzavaite, M., \& Korsakiene, R. (2019). Human Capital and the Internationalisation of SMEs: A Systemic Literature Review. Entrepreneurial Business and Economics Review, 7(3), 125-142. https://doi.org/10.15678/EBER.2019.070307

Cuaresma, J. C., Doppelhofer, G., Huber, F., \& Piribauer, P. (2018). Human capital accumulation and long-term income growth projections for European regions. Journal of Regional Science, 58(1), 81-99. https://doi.org/10.1111/jors.12339

Czapiewski, K., \& Janc, K. (2019). Education, Human Capital and Knowledge-The Paradigm Shift and Future Scenarios on Polish Rural Areas. In J. Bański (Ed.), Three Decades of Transformation in the East-Central European Countryside (pp. 351-367). Springer International Publishing. https://doi.org/10.1007/978-3-030-21237-7_16

Czech Statistical Office. (2021). Public database. https://vdb.czso.cz/vdbvo2/faces/en/index.jsf

Czernich, N., Falck, O., Kretschmer, T., \& Woessmann, L. (2011). Broadband Infrastructure and Economic Growth. The Economic Journal, 121(552), 505-532. https://doi.org/10.1111/j.1468-0297.2011.02420.x

De la Fuente, A., \& Doménech, R. (2006). Human Capital in Growth Regressions: How Much Difference Does Data Quality Make? Journal of the European Economic Association, 4(1), 1-36. https://doi.org/10.1162/jeea.2006.4.1.1

Diebolt, C., \& Hippe, R. (2019). The long-run impact of human capital on innovation and economic development in the regions of Europe. Applied Economics, 51(5), 542-563. https://doi.org/10.1080/00036846.2018.1495820

Ding, C., \& He, X. (2004). K-means clustering via principal component analysis. Proceedings of the Twenty-First International Conference on Machine Learning. https://doi.org/10.1145/1015330.1015408

Egert, B., Botev, J., \& Turner, D. (2020). The contribution of human capital and its policies to per capita income in Europe and the OECD. European Economic Review, 129, 103560. https://doi.org/10.1016/j.euroecorev.2020.103560

Erosa, A., Koreshkova, T., \& Restuccia, D. (2010). How Important Is Human Capital? A Quantitative Theory Assessment of World Income Inequality. Review of Economic Studies, 77(4), 1421-1449. https://doi.org/10.1111/j.1467-937X.2010.00610.x

Etzo, I. (2008). Internal migration and growth in Italy. MPRA Paper 8642. University Library of Munich.

Faggian, A., \& McCann, P. (2006). Human capital flows and regional knowledge assets: A simultaneous equation approach. Oxford Economic Papers, 58(3), 475-500. https://doi.org/10.1093/oep/gpl010 
Faggian, A., \& McCann, P. (2008). Human capital, graduate migration and innovation in British regions. Cambridge Journal of Economics, 33(2), 317-333. https://doi.org/10.1093/cje/ben042

Ferguson, S. (2012). Are public libraries developers of social capital? A review of their contribution and attempts to demonstrate it. The Australian Library Journal, 61(1), 22-33. https://doi.org/10.1080/00049670.2012.10722299

Folloni, G., \& Vittadini, G. (2010). HUMAN CAPITAL MEASUREMENT: A SURVEY. Journal of Economic Surveys, 24(2), 248-279. https://doi.org/10.1111/j.1467-6419.2009.00614.x

Freeman, D. G. (2000). Regional tests of Okun's law. International Advances in Economic Research, 6(3), 557-570. https://doi.org/10.1007/BF02294972

Gennaioli, N., La Porta, R., Lopez-de-Silanes, F., \& Shleifer, A. (2013a). Human Capital and Regional Development*. The Quarterly Journal of Economics, 128(1), 105-164. https://doi.org/10.1093/qje/qjs050

Gennaioli, N., La Porta, R., Lopez-de-Silanes, F., \& Shleifer, A. (2013b). Human Capital and Regional Development*. The Quarterly Journal of Economics, 128(1), 105-164. https://doi.org/10.1093/qje/qjs050

Gruzina, Y., Firsova, I., \& Strielkowski, W. (2021). Dynamics of Human Capital Development in Economic Development Cycles. Economies, 9(2), 67. https://doi.org/10.3390/economies9020067

Graczyk-Kucharska, M., \& Erickson, G.S. (2020). A person-organization fit model of Generation Z: Preliminary studies. Journal of Entrepreneurship, Management and Innovation, 16(4), 149-176. https://doi.org/10.7341/20201645

Grzeszczyk, T. A. (2020). Development of human capital in institutions from the Polish financial sector: Towards new technologies and agile business models. International Entrepreneurship Review, 6(4), 51-63. https://doi.org/10.15678/IER.2020.0604.04

GUS. (2019). Human capital in Poland in the years 2014-2018 (pp. 1-94). Statistics Poland.

Harbison, F., \& Myers, C. A. (1964). Education and Employment in the Newly Developing Economies. Comparative Education Review, 8(1), 5-10. https://doi.org/10.1086/445026

Herbst, M. (2009). Creation and Absorption of Human Capital by the Academic Cities in Poland. Regional and Local Studies, 10(38), 21-38.

Hicks, N., \& Streeten, P. (1979). Indicators of development: The search for a basic needs yardstick. World Development, 7(6), 567-580. https://doi.org/10.1016/0305-750X(79)90093-7

Hierro, M., \& Maza, A. (2010). Per capita income convergence and internal migration in Spain: Are foreign-born migrants playing an important role?*: Income convergence and internal migration in Spain. Papers in Regional Science, 89(1), 89-107. https://doi.org/10.1111/j.1435-5957.2009.00240.x

Honda, K., Notsu, A., \& Ichihashi, H. (2010). Fuzzy PCA-Guided Robust \$k\$-Means Clustering. IEEE Transactions on Fuzzy Systems, 18(1), 67-79. https://doi.org/10.1109/TFUZZ.2009.2036603

Imandoust, S., \& Bolandraftar, M. (2013). Application of K-Nearest Neighbor (KNN) Approach for Predicting Economic Events: Theoretical Background. International Journal of Engineering Research and Applications, 3(5), 605-610.

Jabłoński, Ł. (2021). The Evolution of Approaches to Human Capital in Economics. Gospodarka Narodowa, 306(2), 91-120. https://doi.org/10.33119/GN/134630

Jiménez, M., Matus, J. A., \& Martínez, M. A. (2014). Economic growth as a function of human capital, internet and work. Applied Economics, 46(26), 3202-3210. https://doi.org/10.1080/00036846.2014.925079

Jorgenson, D. W., \& Fraumeni, B. M. (1992). Investment in Education and U.S. Economic Growth. The Scandinavian Journal of Economics, 94, S51. https://doi.org/10.2307/3440246

Kianto, A., Sáenz, J., \& Aramburu, N. (2017). Knowledge-based human resource management practices, intellectual capital and innovation. Journal of Business Research, 81, 11-20. https://doi.org/10.1016/j.jbusres.2017.07.018

Kijek, T., \& Matras-Bolibok, A. (2019). The relationship between TFP and innovation performance: evidence from EU regions. Equilibrium. Quarterly Journal of Economics and Economic Policy, 14(4), 695-709. https://doi.org/10.24136/eq.2019.032

Kijek, A., \& Matras-Bolibok, A. (2020). Technological convergence across European regions. Equilibrium. Quarterly Journal of Economics and Economic Policy, 15(2), 295-313. https://doi.org/10.24136/eq.2020.014

Kırdar, M. G., \& Saracoğlu, D. Ş. (2008). Migration and regional convergence: An empirical investigation for Turkey. Papers in Regional Science, 87(4), 545-566. https://doi.org/10.1111/j.1435-5957.2008.00178.x

Knight, M., Loayza, N., \& Villanueva, D. (1993). Testing the Neoclassical Theory of Economic Growth: A Panel Data Approach. Staff Papers - International Monetary Fund, 4O(3), 512. https://doi.org/10.2307/3867446 
Krueger, A. B., \& Lindahl, M. (2001). Education for Growth: Why and For Whom? Journal of Economic Literature, 39(4), 1101-1136.

Kruskal, W. H. (1952). A Nonparametric test for the Several Sample Problem. The Annals of Mathematical Statistics, 23(4), 525-540. https://doi.org/10.1214/aoms/1177729332

Kruskal, W. H., \& Wallis, W. A. (1952). Use of Ranks in One-Criterion Variance Analysis. Journal of the American Statistical Association, 47(260), 583-621. https://doi.org/10.1080/01621459.1952.10483441

Laskowska, I., \& Dańska-Borsiak, B. (2017). The Importance Of Human Capital For The Economic Development Of EU Regions. Comparative Economic Research. Central and Eastern Europe, 19(5), 63-79. https://doi.org/10.1515/cer-2016-0038

Laureys, L. (2014). The Cost of Human Capital Depreciation During Unemployment. SSRN Electronic Journal. https://doi.org/10.2139/ssrn.2487796

Lim, S. S., Updike, R. L., Kaldjian, A. S., Barber, R. M., Cowling, K., York, H., Friedman, J., Xu, R., Whisnant, J. L., Taylor, H. J., Leever, A. T., Roman, Y., Bryant, M. F., Dieleman, J., Gakidou, E., \& Murray, C. J. L. (2018). Measuring human capital: A systematic analysis of 195 countries and territories, 1990-2016. The Lancet, 392(10154), 1217-1234. https://doi.org/10.1016/S0140-6736(18)31941-X

Linde, Y., Buzo, A., \& Gray, R. (1980). An Algorithm for Vector Quantizer Design. IEEE Transactions on Communications, 28(1), 84-95. https://doi.org/10.1109/TCOM.1980.1094577

Liu, G., \& Fraumeni, B. (2020). A Brief Introduction to Human Capital Measures. No. 13494, p. w27561. IZA Institute of Labor Economics. https://doi.org/10.3386/w27561

Lo, P., \& Stark, A. J. (2020). Shanghai Library as a human capital developer for a knowledge-driven socioeconomic environment. Journal of Librarianship and Information Science, 096100062094856. https://doi.org/10.1177/0961000620948565

Local Data Bank. (2020). Home page. Retrieved from https://bdl.stat.gov.pl/BDL/start on January 25, 2021.

Lorentzen, P., McMillan, J., \& Wacziarg, R. (2008). Death and development. Journal of Economic Growth, 13(2), 81-124. https://doi.org/10.1007/s10887-008-9029-3

Lucas, R. E. (1988). On the mechanics of economic development. Journal of Monetary Economics, 22(1), 3-42. https://doi.org/10.1016/0304-3932(88)90168-7

MacQuenn, J. (1967). Some methods for clasification and analysis of multivariate observations. Proceedings of the Fifth Berkeley Symposium on Mathematical Statistics and Probability, 1(14), 281-297.

Mankiw, N. G., Romer, D., \& Weil, D. N. (1992). A Contribution to the Empirics of Economic Growth. The Quarterly Journal of Economics, 107(2), 407-437. https://doi.org/10.2307/2118477

Manuelli, R. E., \& Seshadri, A. (2014). Human Capital and the Wealth of Nations. American Economic Review, 104(9), 2736-2762. https://doi.org/10.1257/aer.104.9.2736

Manyika, J., \& Roxburgh, C. (2011). The great transformer: The impact of the Internet on economic growth and prosperity. McKinsey Global Institute, 1(0360-8581).

Martín, M.-A. G., \& Herranz, A. Á. (2004). Human capital and economic growth in Spanish regions. International Advances in Economic Research, 10(4), 257-264. https://doi.org/10.1007/BF02295138

Máté, D., Erdei, E., Zeynvand Lorestani, V., Popp, J., \& Oláh, J. (2020). Can internet in schools and technology adoption stimulate productivity in emerging markets? Economics \& Sociology, 13(1), 182-196. https://doi.org/10.14254/2071-789X.2020/13-1/12

Mincer, J. (1958). Investment in Human Capital and Personal Income Distribution. Journal of Political Economy, 66(4), 281-302. https://doi.org/10.1086/258055

Mincer, J. (1981). Human Capital and Economic Growth. No. w0803, p. w0803. National Bureau of Economic Research. https://doi.org/10.3386/w0803

Mincer, J. (1996). Economic Development, Growth of Human Capital, and the Dynamics of the Wage Structure. Journal of Economic Growth, 1(1), 29-48.

Mishchuk, H., Roshchyk, I. Sułkowska, J. \&Vojtovič, S. (2019). Prospects of Assessing the Impact of External Student Migration on Restoring the Country's Intellectual Potential (Case Study of Ukraine). Economics \& Sociology, 12(3), 209-219. DOI: 10.14254/2071-789X.2019/12-3/14 
Ngo, Q.-T., Thai, T.-K. H., Cao, V.-T., Nguyen, A.-T., Hoang, N.-H., \& Nguyen, N.-D. (2020). Individual-level Employment Transitions in Rural Viet Nam. Agris On-Line Papers in Economics and Informatics, 12(01), 73-91. https://doi.org/10.7160/aol.2020.120107

Ogbeifun, L., \& Shobande, O. A. (2021). A reevaluation of human capital accumulation and economic growth in OECD. Journal of Public Affairs. https://doi.org/10.1002/pa.2602

Ogundari, K., \& Awokuse, T. (2018). Human capital contribution to economic growth in Sub-Saharan Africa: Does health status matter more than education? Economic Analysis and Policy, 58, 131-140. https://doi.org/10.1016/j.eap.2018.02.001

Oliinyk, O., Bilan, Y., Mishchuk, H., Akimov, O., \& Vasa, L. (2021). The Impact of Migration of Highly Skilled Workers on The Country's Competitiveness and Economic Growth. Montenegrin Journal of Economics, 17(3), 719. https://doi.org/10.14254/1800-5845/2021.17-3.1

Pater, R., \& Lewandowska, A. (2015). Human capital and innovativeness of the European Union regions. Innovation: The European Journal of Social Science Research, 28(1), 31-51. https://doi.org/10.1080/13511610.2014.962487

Piętak, Ł. (2014). Review Of Theories And Models Of Economic Growth. Comparative Economic Research. Central and Eastern Europe, 17(1), 45-60. https://doi.org/10.2478/cer-2014-0003

Piętak, Ł. (2021). Structural Funds and Convergence in Poland. Hacienda Publica Espanola, 236, 3-37. https://doi.org/10.7866/HPE-RPE.21.1.1

Ritsilä, J., \& Ovaskainen, M. (2001). Migration and regional centralization of human capital. Applied Economics, 33(3), 317-325. https://doi.org/10.1080/00036840122485

Romer, P. M. (1986). Increasing Returns and Long-Run Growth. Journal of Political Economy, 94(5), 1002-1037.

Roszko-Wójtowicz, E., Grzelak, M. M., \& Laskowska, I. (2019). The impact of research and development activity on the TFP level in manufacturing in Poland. Equilibrium. Quarterly Journal of Economics and Economic Policy, 14(4), 711-737. https://doi.org/10.24136/eq.2019.033.

Sacco, P. L., \& Segre, G. (2009). Creativity, Cultural Investment and Local Development: A New Theoretical Framework for Endogenous Growth. In U. Fratesi \& L. Senn (Eds.), Growth and Innovation of Competitive Regions (pp. 281-294). Springer Berlin Heidelberg. https://doi.org/10.1007/978-3-540-70924-4_13

Sachs, J. (2001). Macroeconomics and health: Investing in health for economic develoopment. World Health Organization.

Shachmurove, Y., \& Zilberfarb2, B. (2020). Macroeconomic performance of the Israeli economy in the 21st millennium. Economics and Business Review EBR 20(2), 45-65 DOI: 10.18559/ebr.2020.2.4

Schultz, T. (1961). Investment in Human Capital. The American Economic Review, 51(1), 1-17.

Scott, R. (2011). The Role of Public Libraries in Community Building. Public Library Quarterly, 30(3), $191-227$. https://doi.org/10.1080/01616846.2011.599283

Sen, A. (1980). Equality of What? The Tanner Lecture on Human Values, I, 197-220. https://www.ophi.org.uk/wpcontent/uploads/Sen-1979_Equality-of-What.pdf

Shafuda, C. P. P., \& De, U. K. (2020). Government expenditure on human capital and growth in Namibia: A time series analysis. Journal of Economic Structures, 9(1), 21. https://doi.org/10.1186/s40008-020-00196-3

Simionescu, M., Ciuiu, D., Bilan, Y., \& Strielkowski, W. (2016). GDP and Net Migration in Some Eastern and South-Eastern Countries of Europe. A Panel Data and Bayesian Approach. Montenegrin Journal of Economics, 12(2), 161-175.

Sjaastad, L. A. (1962). The Costs and Returns of Human Migration. Journal of Political Economy, 70(5, Part 2), 8093. https://doi.org/10.1086/258726

Soylu, Ö. B., Çakmak, i., \& Okur, F. (2018). Economic growth and unemployment issue: Panel data analysis in Eastern European Countries. Journal of International Studies, 11(1), 93-107. https://doi.org/10.14254/20718330.2018/11-1/7

Stejskal, J., Hájek, P., \& Řehák, T. (2019). The economic value of library services for children: The case of the Czech public libraries. Library \& Information Science Research, 41(3), 100963. https://doi.org/10.1016/j.lisr.2019.100963

Stewart, F., Ranis, G., \& Samman, E. (2018). Advancing human development: Theory and practice (First edition). Oxford University Press.

Tano, S. (2014). Regional clustering of human capital: School grades and migration of university graduates. The Annals of Regional Science, 52(2), 561-581. https://doi.org/10.1007/s00168-014-0599-z 
Tibshirani, R., Walther, G., \& Hastie, T. (2001). Estimating the number of clusters in a data set via the gap statistic. Journal of the Royal Statistical Society: Series B (Statistical Methodology), 63(2), 411-423. https://doi.org/10.1111/1467-9868.00293

Tvaronavičienė, M., Mazur, N., Mishchuk, H., \& Bilan, Y. (2021). Quality of life of the youth: assessment methodology development and empirical study in human capital management. Economic ResearchEkonomska Istraživanja, 1-18. DOI:10.1080/1331677X.2021.1956361

UNDP (2020). The next frontier: Human development and the Anthropocene. United Nations Development Programme.

UNESCO. (2017). EU cohesion policy (regional policy). Retrieved from https://en.unesco.org/creativity/policymonitoring-platform/eu-cohesion-policy-regional on June 24, 2021.

United Nations. (2016). Guide on Measuring Human Capital. United Nations Economic Commission for Europe. Retrieved from https://unstats.un.org/unsd/nationalaccount/consultationDocs/HumanCapitalGuide.web.pdf on June 24, 2021.

United Nations. (2021). Human Development Data Center. Retrieved from http://hdr.undp.org/en/data on June 24, 2021.

Vårheim, A. (2009). Public libraries: Places creating social capital? Library Hi Tech, 27(3), $372-381$. https://doi.org/10.1108/07378830910988504

Wang, S. L., \& Cuervo-Cazurra, A. (2017). Overcoming Human Capital Voids in Underdeveloped Countries: Overcoming Human Capital Voids. Global Strategy Journal, 7(1), 36-57. https://doi.org/10.1002/gsj.1144

Ward, J. H. (1963). Hierarchical Grouping to Optimize an Objective Function. Journal of the American Statistical Association, 58(301), 236-244. https://doi.org/10.1080/01621459.1963.10500845

Weinberger, M. (2014). An overarching health indicator for the Post-2015 Development Agenda (p. 15).

Wilson, R. A., \& Briscoe, G. (2004). The impact of human capital on economic growth: A review. Impact of Education and Training. Third Report on Vocational Training Research in Europe: Background Report. Luxembourg: EUR-OP, 9-70.

Wojciechowska, M. D. (2021). The role of public libraries in the development of social capital in local communities - a theoretical study. Library Management, 42(3), 184-196. https://doi.org/10.1108/LM-10-2020-0139

Wolszczak-Derlacz, J. (2009). The impact of internal and international migration on regional convergence in Poland. In M. Duszczyk \& M. Lesińska (Eds.), Współczesne migracje: Dylematy Europy i Polski (pp. 92-117). Ośrodek Badań nad Migracjami Uniwersytetu Warszawskiego.

World Bank. (2010). The Changing Wealth of Nations: Measuring Sustainable Development in the New Millennium. The World Bank. https://doi.org/10.1596/978-0-8213-8488-6

World Bank. (2021). Human Capital Project. Retrieved from https://www.worldbank.org/en/publication/humancapital on June 24, 2021.

World Economic Forum. (2017). The global human capital report 2017: Preparing people for the future of work. Retrieved from https://weforum.ent.box.com/s/dari4dktg4jt2g9xo2o5pksjpatvawdb on June 24, 2021.

$\mathrm{Xu}, \mathrm{Y} .$, \& Li, A. (2020). The relationship between innovative human capital and interprovincial economic growth based on panel data model and spatial econometrics. Journal of Computational and Applied Mathematics, 365, 112381. https://doi.org/10.1016/j.cam.2019.112381

Yusoff, W. F., Jantan, M., \& Ibrahim, D. N. (2004). The Interactive Effects Of Human Capital, Structural Capital And Social Capital On Firm Performance. Asian Academy of Management Journal, 9(2), 1-18.

Zikic, J. (2015). Skilled migrants' career capital as a source of competitive advantage: Implications for strategic HRM. The International Journal of Human Resource Management, 26(10), 1360-1381. https://doi.org/10.1080/09585192.2014.981199 


\section{Authors}

The contribution of authors is as follows: $\mathrm{MW}-25 \%$ (conceptualisation, literature writing, methodology, calculations, discussion, project administration); DC - 20\% (conceptualisation, literature writing, methodology, calculations, discussion); KC $-20 \%$ (conceptualisation, literature writing, methodology, calculations, discussion, project administration); PK - 20\% (conceptualisation, literature writing, calculations, discussion); $Ł G-10 \%$ (conceptualisation, literature writing, methodology, discussion); LS - 5\% (supervision, project administration)

\section{Michał Wielechowski}

PhD in Economics; Assistant Professor at the Warsaw University of Life Sciences - SGGW (Poland). His research interests include macroeconomics, economic analysis, political economics.

Correspondence to: Dr Michał Wielechowski, Warsaw University of Life Sciences-SGGW, Institute of Economics and Finance, Nowoursynowska 166, 02-787 Warsaw, Poland, e-mail: michal_wielechowski@sggw.edu.pl ORCID $\odot$ http://orcid.org/0000-0002-1335-8971

\section{Denys Cherevyk}

MSc; PhD student at the Warsaw University of Life Sciences - SGGW (Poland). His research interests include econometrics, economic modelling, regional analysis.

Correspondence to: Mgr Denys Cherevyk, Warsaw University of Life Sciences - SGGW, Institute of Economics and Finance, Nowoursynowska 166, 02-787 Warsaw, Poland, e-mail: denys_cherevyk@sggw.edu.pl ORCID $\odot$ http://orcid.org/0000-0001-9744-4502

\section{Katarzyna Czech}

PhD in Economics; Assistant Professor at the Warsaw University of Life Sciences - SGGW (Poland). Her research interests include international economics, economic modelling, financial econometrics.

Correspondence to: Katarzyna Czech, PhD, Warsaw University of Life Sciences - SGGW, Institute of Economics and Finance, Nowoursynowska 166, 02-787 Warsaw, Poland, e-mail: katarzyna_czech@sggw.edu.pl ORCID $\odot$ http://orcid.org/0000-0002-0660-7124

\section{Pavel Kotyza}

PhD in Economics; Assistant Professor at the Czech University of Life Sciences Prague (Czech Republic). His research interests include development economics, economic modelling, financial econometrics.

Correspondence to: Pavel Kotyza, PhD, Czech University of Life Sciences Prague, Faculty of Economics and Management, Kamycka 129, 16521 Praha 6 - Suchdol, Czechia, e-mail: kotyza@pef.czu.cz ORCID $\odot$ http://orcid.org/0000-0002-7706-7372

\section{Łukasz Grzęda}

MSc; PhD student at the Warsaw University of Life Sciences - SGGW (Poland). ). His research interests include regional analysis, macroeconomics, human capital analysis.

Correspondence to: Mgr Łukasz Grzęda, Warsaw University of Life Sciences - SGGW, Institute of Economics and Finance, Nowoursynowska 166, 02-787 Warsaw, Poland, e-mail: lukasz_grzeda@sggw.edu.pl

ORCID $\odot$ http://orcid.org/0000-0002-2681-3208

\section{Lubos Smutka}

Professor in Economics; Professor at the Czech University of Life Sciences Prague (Czech Republic). His research interests include economic development, international business, international trade.

Correspondence to: Prof. Lubos Smutka, PhD, Czech University of Life Sciences Prague, Faculty of Economics and Management, Kamycka 129, 16521 Praha 6 - Suchdol, Czechia, e-mail: smutka@pef.czu.cz

ORCID $\odot$ http://orcid.org/0000-0001-5385-1333 


\section{Conflict of Interest}

The authors declare that the research was conducted in the absence of any commercial or financial relationships that could be construed as a potential conflict of interest.

\section{Copyright and License}

This article is published under the terms of the Creative Commons

Attribution - NoDerivs (CC BY-ND 4.0) License

http://creativecommons.org/licenses/by-nd/4.0/

Published by Cracow University of Economics - Krakow, Poland 